\title{
Celtic Environments: Welsh Industrial Landscapes through French Travelogues
}

Dr Heather Williams

University of Wales Centre for Advanced Welsh and Celtic Studies

National Library of Wales

Aberystwyth

SY23 3BU

Wales

h.williams@wales.ac.uk

\section{Word Count}

6068

\section{Keywords}

Wales, Brittany, travel writing, industry, Celtic

\begin{abstract}
It has rightly been argued that the growth of the cult of the local in France has to do with France's need to re-invent its own past in the wake of the Revolution of 1789. This article suggests the importance of the Industrial Revolution, and changes to physical environments in this same development, by analysing travelogues by Celtomaniac French visitors to Wales in the 1860s. Unlike their own Celtic land, Brittany, Wales was a place where the issues of modernization, industrialization and changes to the local environment met head on with that of the survival of an ancient indigenous culture.
\end{abstract}

\section{Note on Contributor}

\section{Note on Contributor}

Heather Williams read Modern Languages (French) at St. Hilda's College, Oxford, and has specialized in crosscultural, comparative work in French and Celtic Studies. She has published widely on nineteenth-century French literature, particularly the literature of Brittany, and has a strong interest in translation studies, postcolonial studies and ecocriticism. Recently her work has focused on cultural exchange between French, Breton, Welsh and English, as well as travel writing. She was Co-I on the AHRC-funded 'European Travellers to Wales: 1750-2010' project. Her publications include Mallarmé's Ideas in Language (2004) and Postcolonial Brittany: Literature Between Languages (2007).

Industrial advances in Western Europe coincide with the growth in popularity of the Celts, and thus far there has been no attempt to untangle the two. Juxtaposing descriptions of France's most Celtic region — Brittany — with travelogues depicting the unexpected combination of industrial prowess and Celticity found in Wales, shows clearly that French Celtophilia may have just as much to do with the Industrial Revolution as that of 1789 . This article considers a selection of nineteenth-century French travelogues that treat mineral or economic resources together with cultural capital. Comparing travelogues on two different Celtic regions - one at home (Brittany) and the other (Wales) located within the main industrial competitor (Great Britain) - allows for an innovative perspective on regionalism. 


\section{Williams, 2/21}

And a crosscultural investigation of environmental sensibilities will test the argument made by Caroline Ford that, in its French form, "environmental anxiety" is especially connected to nostalgia and "a longing for the preservation of both peopled and unpeopled landscapes and traditional ways of life" $(2016,7)$.

The confident view of technological knowledge emanating from Britain towards the Continent, rather like the idea of Enlightenment as a light shining from Paris onto darker and peripheral regions, has been challenged by historians, who have more recently explored ways in which "knowledge and technology flows were never one-way" (Jones 2016, 12). There is little doubt that the Industrial Revolution led to anxieties about France's role on the world stage, and following the Napoleonic Wars, an "intense sense of national rivalry with the other rising power across the Channel" (Harris 1992, 16) fuelled nationalism and colonial expansion in France. Though the old assumption of "Continental emulation" (Landes [1969] 2003) can no longer hold, travelogues display anxiety and envy along with a desire to copy and compete,.Such anxiety is notably absent from eighteenth-century travel writing, such as that by Charles-Étienne Coquebert de Montbret (1755-1831) who travelled through Wales in 1789. In his diary, sites of industry are listed purely in the interest of producing an encyclopaedic and thorough account, and are not presented in terms of anxious comparisons with developments at home in France (Coquebert de Montbret 1995).

This changes after 1815, when French industrial travelogues begin to show not only anxiety but also paranoia about intellectual property and industrial espionage. Perceived British successes in industry are debated, and travellers ask whether Britain has merely been fortunate to be blessed with such rich mineral deposits: "la nature a tout donné" (Simonin $1865,343)$, or whether success is the result of sheer hard work, made possible by the Brits' "cold" character (Smyers Jr 1858, 20)? For Alphonse Esquiros, forced to flee France for political reasons, and therefore possibly displaying anti-State sentiment, Britain's industrial 


\section{Williams, 3/21}

advantage is the result of hard work and good management: "les grandes industries ne naissent point avec les nations; elles deviennent, elles se développent" (1865b, 801, emphasis in original). Just as French industrialists concentrated "overwhelmingly" on the British example (Harris 1998, 2), French scholars and antiquarians turned to Britain's medieval Celtic texts, with some turning to Wales for inspiration (Glencross 1995, 132). Just like the story of industrila expansion, the editing of medieval texts was inseparable from nationalism, in France as elsewhere (Utz 2016, 128). The travelogues discussed here focus on the relationship between industrialization/environment and Celticity.

\section{Brittany}

Bretons were seen in opposition to modernization - as backward, irrational, otherworldly, in decline, and fit only for the museum or tourism, mostly because industrialization was not happening on a large scale in Brittany, ${ }^{1}$ but also because of what has been termed the "place myth” of Brittany (Coughlin 2013, 67 [following Lübbren 2001, 115]). At a time when France was keen to modernize and compete internationally, Francophone narratives of Brittany only allow this region to be either inferior or else a venerated Celtic relic. Indeed, even when it did possess extractable resources, these were not perceived as such, as art historians have pointed out, not least in the case of seaweed collecting (Lübbren 2001, 13; Coughlin 2016). While seaweed harvesting is frequently presented by nineteenth-century painters as a primitive peasant activity, and even treated by later curators and historians as a picturesque detail that may be thrown into paintings, more recent work has stressed that it was a rather sophisticated industry and a "cash crop" (Orton and Pollock 1980, 324). Art historians have analysed the misuse of this visual reference to show how the myth of Brittany's remoteness and primitivism endured far beyond real advances in agriculture (Coughlin 2016, 12-15). 


\section{Williams, 4/21}

The founding text of modern Francophone writing about Brittany is Jacques Cambry's Voyage dans le Finistère (1798). Already President of the Quimperlé discrict, Cambry was instructed by State administrators in 1794 to inventory objects of interest to the advancement of human knowledge in Finistère, from statues to seashells, manuscripts to mathematical instruments (Cambry 2011, xxxiii). The resulting travelogue opens in the area around Morlaix, with an emphasis on its rurality: "ce pays est, sans exception, le plus champêtre et le plus pittoresque de la France" ([1798] 2011, 6). Though aesthetics are important to him (having been inspired by London's parks, 82-83), his main concern is that Brittany's land needs improving. The potential is there, but agriculture must be modernized, peasants educated, yields increased, and infrastructure improved, as at St.-Pol-de-Léon: "la nudité qui frappe le voyageur, n'est pas l'effet d'un mauvais sol: [...] augmentez l'industrie, et bientôt ces déserts seront couverts d'arbres, de fleurs, de moisson, de prairies" (82). While he blames Brittany's distance from Paris for this lack of development, he suggests that it would nevertheless give a better return on investment than Saint-Domingue (139).

Environmental concern is absent from Cambry's detailed discussion of the mines at Huelgoat (147). When noting that their effluent is killing fish and trees along the river, and causing lead poisoning in peasants, rather than express condemnation or concern he simply notes that it is a matter for engineers to determine whether canals should be built for the waste. Similarly, although he claims that the mines consume too much wood, this only worries him because he fears it will cause a shortage of fuel for people in a cold winter (250). There is only a desire for progress here, and no concern for damage to the natural environment. Indeed, he seems more interested in the Bretons' privileged relationship with their natural environment, since this conjures up a Druidic past and bolsters their claim to authentic Celticity: 'l'oiseau qui chante répond à leurs questions [...]; les hurlemens d'un chien leur annonce la mort" (45). The discourse inaugurated by Cambry is one that sees 


\section{Williams, 5/21}

Brittany as a "relic region" (Hopkin 2012, 33), left behind by State administrators, and kept backward by the Catholic Church, but bursting with agricultural potential, and boasting scenery to rival that of Switzerland and Italy (280). This sets the tone for Francophone representations of Brittany until the twentieth century.

After Cambry, commentators continue to stress not only the need for modernization, but also the Bretons' stubbornness and refusal to evolve. The particularly condemning souspréfet Auguste Romieu claims that in Brittany “on ne saurait pousser plus loin la haine des innovations" (1829, 159). In 1840-41, Louis-François Benoiston de Châteauneuf and LouisRené Villermé, two Parisians tasked with preparing a report on Brittany for the Académie Royale des Sciences Morales et Politiques, describe the need for a "défrichement urgent de la Bretagne" (Benoiston de Châteauneuf and Villermé 1844, 20). The same attitude is found in fiction. In Balzac's early novel Les Chouans (1829), Parisian characters find both people and place "retardés," ([1829] 1972, 124), and this backwardness is blamed on Brittany's flora, fauna and terrain:

Là, le génie de la civilisation moderne s'effraie de pénétrer à travers d'immenses forêts primordiales. [...] Ce malheur s'explique assez par la nature d'un sol encore sillonné de ravins, de torrents, de lacs et de marais; hérissé de haies, espèces de bastions en terre qui font, de chaque champ, une citadelle; privé de routes et de canaux. (39)

Travellers such as Balzac, who visited Brittany in order to research Les Chouans, are not actually expecting to find modern civilization in Brittany. Romieu and Balzac were hoping that their descriptions and polemic would and demonstrate why benighted Brittany needed help to modernize. The Celtophiles who travelled around Brittany in the wake of Cambry searching for songs and traditions, were not expecting to find modernity here either. Instead they were seeking cultural capital to bolster France's case as a nation with a coherent and rich 


\section{Williams, 6/21}

heritage (Dietler 1994). The result of this is that Brittany was not expected to, and eventually not allowed to, have a successful industry in French discourse, as we saw in the case of seaweed.

\section{Wales}

Merthyr Tydfil, a town in south Wales which expanded rapidly with the growing demand for iron, is described as world-leading by no less a figure than Paul Vidal de la Blache (18451918), the founder of modern French Geography: "Merthyr-Tydfil, dans l'intérieur, est une réunion de hauts fourneaux comme il y en a peu dans le monde" (Vidal-Lablache 1889, 289). This industrial prowess is not confined to the south - in north Wales on the lookout for technical tips, Smyers Jr claims that Penrhyn Quarry "n'a pas son pareil dans le monde" $(1858,8)$, and adds with regret that it even exports slate to France: "je l'ajoute à regret" (12). The Dufauds - owners of the Fourchambault Works in the Nivernais, and connected by marriage to the Crawshays who owned Cyfarthfa Ironworks — spent time in Merthyr Tydfil because Wales provided a useful model for them. In summer 1823, Achille Dufaud (17961856) expresses envy in his letters home to his father Georges (1777-1852): “d'après tout ce que je vois et j'entends ici, nous avons encore beaucoup à faire pour arriver au même ordre. [...] Le pays de Galles et Cyfarthfa surtout a et conserve les meilleurs puddleurs du monde" (Dufaud 1823, cited in Thuillier 1959, 225). His letters also display frustration that their own works are lagging: "si nous pouvions avoir un résultat moyen et annuel aussi satisfaisant, quelle différence!" (225), and urges his father to keep up: "il faut absolument que nous fassions de même le plus tôt possible" (226). Paranoia about espionage also surfaces in Achille's letters (228), just as it does in the travelogue by M. L. Simonin describing the difficulty of arranging a visit to John Vivian's copper factory in Swansea for a French party. They are finally granted permission to visit just once, on condition that they refrain from making detailed sketches or taking measurements (Simonin 1865, 326). 


\section{Williams, 7/21}

However, many French-Welsh industrial connections were forged during the course of the nineteenth century (Belhoste and Woronoff 2005), as French entrepreneurs became determined to emulate the "best" industrial practices that could be observed in Britain. Students from Parisian écoles were regularly sent to Wales to observe and learn: Frédéric Le Play (1806-82), Professor of Metallurgy at the École des Mines, visited Swansea’s copperworks on three occasions between 1836 and 1843. By the 1860s it was acknowledged as an ideal case study; according to Simonin, who had travelled the world to study mines before visiting Wales in 1862, "le pays de Galles [...] mérite à tous les égards d'attirer l'attention du savant, de l'ingénieur et de l'industriel" (1865, 347). Alphonse Esquiros agrees (1865b, 805), but is also unafraid of social comment, which may be unsurprising — given his background - but perhaps unexpected in a guidebook:

En dépit de cette prospérité industrielle, la ville [Merthyr] est sale, triste, malsaine, à cause de l'accumulation des habitants dans des rues étroites et fangeuses. [...] Il serait temps que ceux qui profitent de ces travaux, sources de si grandes richesses, songeassent à améliorer l'état du peuple (1865a, 201).

What he sees are martyrs to industry: "l'industrie, religion des temps modernes, aurait-elle donc ses martyrs, comme l'indique le nom même de la ville?" (1865b, 831). He employs deathly imagery—one must cross the Styx, so to speak, to reach the iron works: "on arrive aux Cyfarthfa iron-works en traversant des chemins fangeux et un canal qui a la couleur du Styx. O belle rivière Taff, qu'a-t-on fait de tes eaux?" (833). The morbid imagery continues when his description of abject poverty on the streets of Merthyr Tydfil switches to a description of a shadowy funeral procession of four or five hundred mourners beneath large umbrellas, barely visible through the rain (831).

Esquiros is the most political of the travellers considered in the present article. The effects of industrialization and the pollution caused by it are further conveyed in Esquiros's 


\section{Williams, 8/21}

image of a rasping harp $(1865 \mathrm{~b}, 815)$ : Welsh culture, represented by this emblem and tourist attraction, has been "conquered" — "une race conquise" — by the English "vainqueurs" (816). The joint issues of the decline of Welsh cultural difference and the impact of industry on the natural environment here become difficult to untangle:

À Neath, un jour de pluie, dans une des rues le plus tristes et les plus mal famées de cette ville obscurcie par la fumée des usines, j'entendis sortir d'un rez-de-chaussée à l'apparence suspecte et aux vitres dépolies le son d'une harpe éraillée (815).

Esquiros, however, has no desire to reverse this acculturation, since he sees Welsh as unsuited to modern developments: "cet idiome [...] n'a point du tout été fait pour une époque d'industrie, de commerce et de transactions pécunaires" (825). He predicts that things will go the way that they have gone in Cornwall: “c'est surtout l'industrie des mines qui a effacé de la Cornouaille l'ancien langage breton" (826).

Esquiros's article also displays a concern for the impact of industry on nature. On his journey towards Merthyr Tydfil, the language of injury ("blessure") and violence ("coupées, dénudées, tourmentées") is used to convey the damage to the natural environment that he witnesses though the window of the train:

Le spectacle extérieur se modifie: l'agriculture et l'industrie semblent se disputer le terrain. De petits moutons welshes, à la laine noircie par le brouillard et par la fumée des usines, errant encore dans les prairies herbues, qui, abritées par de hautes collines, restent vertes en dépit des étés les plus secs. Plus loin, c'est l'industrie qui triomphe. Des rubans de fer couronnent le front des hauteurs, sur lesquelles courent de petits wagons chargés de minerai ou de charbon de terre, et qui sortent sans doute des bouches de la mine. Les collines, coupées, dénudées, tourmentées dans leurs escarpements, accusent en vigueur sur un fond brumeux les blessures qu'elles ont 


\section{Williams, 9/21}

reçues de la main de l'homme! De tous les côtés de l'horizon, de longs tuyaux de brique font de la fumée dans du brouillard. Des bouffées de feu s'échappent à distance de sombres soupiraux, comme si c'était le sol lui-même qui brûlât. Le ciel en est noir; la campagne étouffe en quelque sorte dans un bain de vapeur. (1865b, 827 [emphasis added])

Once again, he conveys violence when describing the construction of Cyfarthfa Ironworks: “construite dans l'épaisseur d'une colline éventrée par la pioche” (833 [emphasis added]). For Esquiros, the culture, poetry and art of Wales are dying, and he feels witness to "les derniers échos d'une nationalité expirante" $(1865 b, 842)$. The contrast with life inside cutting-edge Welsh factories could not be greater: "dans les usines au contraire, où l'on ne s'enivre point des fictions du passé, quel changement! Le feu, l'eau, la vapeur, les machines, les hommes, tout lutte, tout produit, tout vit" (842). The Celts, it seems, will enter modernity for the price of their poetry.

Simonin visits south Wales for professional reasons, having just undertaken a tour of Cornish copper and tin mines. According to him too, the factories in Wales are unrivalled $(1865,321)$, but he is also intrigued by the culture that has shown such resilience: "ses mœurs"; "sa langue propre" $(321,331)$. However, he delegates the job of describing the Eisteddfod - a Welsh cultural gathering — to Esquiros, and quotes the latter's account verbatim (332) before summing up with the claim that metallurgical industries and tourism are wiping out the Celtic language and customs of Wales (336). He predicts that the Welsh people will survive, but that their language, which is wholly unsuited to modern life and business, will die, just like Cornish (336). What he is most concerned by is the poverty that he sees among the workers, and is disgusted by "la misère galloise" (339), for only in London has he seen scenes this bad (339). At Swansea, he describes the damage to the environment caused by industry: “ces vapeurs empestées, en se répandant dans l'air ambiant, ont tué toute 


\section{Williams, 10/21}

végétation, pelé, calciné la roche avoisinante, de telle façon qu'aucune culture n'est possible dans un rayon de plusieurs milles autour des usines à cuivre" (326). But matters worsen as he approaches Merthyr Tydfil, and turns his attention to the workers. He is appalled by the coexistence of such poverty and prosperity:

Ici tout prenait un ton triste, sale et misérable, comme si le charbon et le fer ne pouvaient aller qu'avec la boue et la malpropreté [...]. A Merthyr, la ville elle-même offre un aspect triste et rebutant. Les rues ne sont ni balayées, ni lavées; la crotte et l'ordure s'y entassent; une poussière noire, produite par la fumée et le charbon, s'étend sur les façades des édifices et jusque sur les vêtements et la figure des habitants. Dans un tel milieu, le laisser aller, la négligence, puis la misère prennent vite droit de cité, et voilà comment s'explique peut-être le spectacle navrant dont une portion de la classe ouvrière de Merthyr nous rendit trop souvent témoins. (339)

Despite this, he manages to find a coal mine picturesque: "la maison du puits, la cheminée de la machine à vapeur d'extraction couronnent assez pittoresquement le coteau" (331).

For Celtic enthusiasts in France, on the other hand, the astonishing and exciting discovery is that Wales, unlike Brittany, is an area where Celtic culture and language endure alongside cutting-edge industry, which provides living proof that Celticity and industrialization are compatible. In Welsh travelogues by French visitors, issues of modernization, industrialization and changes to the local environment meet with the French past head on, in a way that was impossible in Breton texts because of the lack of industrial development. Henri Martin has been described as a "Celtomaniac" (Glencross 1995, 111; Williams 2006), and his trip to Wales must be understood within a tradition of French Celtophilia beginning with the Académie celtique, which, in the wake of the Revolution, sought to understand the origins of France. Henri Martin seeks to prove that an ideal balance of modernity (industry) and tradition (Celticity) is possible, but some alarming blind spots 


\section{Williams, 11/21}

betray his pro-Celtic agenda. Martin came to Merthyr Tydfil not to see world-leading industry, but rather to undertake research for a book on the notorious forger of Welsh medieval texts Iolo Morganwg (bardic name of Edward Williams) (Williams 2019). Just like his idol Iolo, Martin's brand of Celtophilia was political as well as cultural, and he "found in ancient Celtic traditions the idea of progress, a sanction for individuality, and the seed of French liberty" (Rearick 1974, 115).

Despite being in Wales for scholarly reasons, Henri Martin is impressed by the fact that south Wales is a world leader in industry: "nulle part au monde plus de fer ne passe par la fournaise" $(1872,35)$. At first, he does not realize that the hills on either side of the road are fake, and describes the man-made slagheaps being harmoniously re-absorbed into nature:

Il se forme ainsi de nouveaux mamelons qui, toujours accrus de nouvelles scories, brûlent durant des années jusqu'à ce qu'on les laisse s'éteindre; avec le temps, ils se couvrent de verdure et cachent peu à peu la trace de leur origine en entrant dans le domaine de la végétation et de la vie. (35)

What he optimistically perceives in the landscape is industry and productivity balanced with a "nature presque sauvage," complete with medieval ruins:

Ces villes sont plutôt de grands villages espacés dans les vallées et sur les collines que de noirs entassements d'habitations compactes comme les cites industrielles des autres provinces; l'aspect de ce pays est extraordinaire; il n'est pas triste; il offre le mélange et le contraste d'une vaste industrie et d'une nature agreste et presque sauvage. Vous êtes au milieu des ateliers, les colonnes de fumée jaillissent de toutes parts autour de vous; vous grimpez sur le dos d'une colline, vous changez de vallée, vous voilà au milieu des bois, des rochers, des cascades, avec quelque grande ruine du moyen âge sur votre tête, et un large horizon de montagnes devant vous. (36) 


\section{Williams, 12/21}

He is resolutely optimistic about the future of Welsh poetry and tradition: "la poésie et la tradition venaient s'installer au cœur de l'industrie moderne" (49). He is delighted to note that the Welsh language survives even in the most industrial of areas (37), and insists that it is adequate for every aspect of the modern world (53). There is also a pan-Celtic aspect to his vision, as the music at the Eisteddfod at Aberdare reminds him of Breton airs, and he makes a comparison with Brittany when walking around Holyhead: “j’arrivai à un promentoire dont les rochers abruptes et déchirés dominent d'aussi loin le vaste Océan que les plus fiers de nos caps de Bretagne" (48). However, despite appearing to advocate solidarity between peripheral Celts, his ultimate concern is to unite Frenchmen in devotion to their new Republic: "la Patrie" is always paramount as the guarantor of France's strength in the world. His rhetoric displaying an uncritical belief in the French mission civilisatrice has been described as "deliciously Gallocentric" (Hazareesingh 2015, 146).

Alfred Erny was Martin's travel companion, and shared Martin's pro-Celtic and thus pro-Welsh agenda. This is evident in the way that he projects a Wales of harmony and balance. At Swansea, there is no doubt how poisonous industry is:

La vallée de Swansea, où l'air est vicié par les vapeurs arsenicales et sulfureuses des manufactures de cuivre. Partout le sol est aride et dégarni de verdure; on affirme pourtant que cette atmosphère n'est pas pernicieuse aux ouvriers, et qu'un grand nombre d'entre eux arrivent à un âge très-avancé. (Erny 1867, 263)

The air is "vicié," the fumes contain arsenic and sulphur, and the ground is barren. Yet, for Erny, these conditions pose no threat to the workers' health, as many of them apparently live well into old age. When he reports that workers at furnaces only live a few years, the absence of condemnation is glaring (271). His description of Merthyr Tydfil clearly betrays the reason for his environmental blindspots, which is his pro-Celtic agenda: 


\section{Williams, 13/21}

C'est la ville manufacturière par excellence, et longtemps avant d'y arriver, l'atmosphère est noircie par des nuages de fumée: la route passe à travers des montagnes de cendre qui me rappellent l'aspect aride d'Aden: quelques-unes brûlent encore. [...] La nuit la vallée est illuminée par ces flammes; si bien qu'à l'époque où lord Guest habitait Dowlais (vaste village industriel qui lui appartient presque en entier), il n'avait pas besoin de bougies, car la lueur des forges éclairait ses appartements comme en plein jour.

Lady Charlotte Guest a rendu un grand service à la littérature galloise en publiant les Mabinogion, anciens contes celtiques. (270)

The iron capital of the world is presented as a Celtic paragon of progress, where the relationship between industry and Welsh culture is symbiotic. Projecting back to the 1830 s, Erny's portrait presents the Dowlais works as leading the world in iron, while Lady Charlotte Guest is at the forefront of Celtic philology in translating medieval Welsh prose tales, the Mabinogi. According to the stark juxtaposition in the text, she completes this work by the light of the forges, allowing industrial progress to exist in a harmonious union with the Celtic revival. On a practical level, Charlotte Guest cut her teeth as a translator on French industrial texts - as her first translation (1836) was a pamphlet on ironworking by Dufrésnoy (Davies 2004, 160). On the level of textual detail, industrial progress can be seen to power the Celtic revival by providing an apprenticeship in the field of translation, as well as the midnight oil to inspire and illuminate her race to translate medieval Welsh texts into English. ${ }^{2}$

The search for Celticity was the real reason why Erny was in Wales (Williams 2019). Although it happens to be one of the most industrialized regions of Europe, he still manages to project an idyll of white clouds emerging from chimneys, rather than pollution: "collines arides, à moitié ensevelies dans les vapeurs grises du ciel et les nuages blancs des fabriques" $(1867,263)$. Further, he concocts a story of Celticity to mask environmental damage and 


\section{Williams, 14/21}

human suffering, in substituting mythical Celtic figures — “frappeurs" —for working, suffering humans. When he explains that he took an omnibus excursion to the Gower on account of "le caractère sauvage de ses côtes" and the area's reputation for being full of "antiquités" (263), we see that he is searching for the "sauvage," the picturesque and the ancient. His search in the Neath Valley leads him to some waterfalls, and-more significantly - the otherworldly, which culminates in a discussion of the importance of the supernatural for this "peuple nerveux et poétique" (266). He subverts the whole rhetoric of progress by turning Wales's success in mining back to a Celtic predilection for otherworldliness: "quelques-unes des plus belles mines du pays de Galles passent pour avoir été découvertes par les Frappeurs" (288). His travelogue ends, then, not with an account of cutting-edge south Wales industry, but with a story of supernatural little beings that inhabit mines, the Cnocwyr ("frappeurs"). The otherworldly seems inescapable in any description of Celts, even when the topic of discussion is industrialization and modernization. Analysis of textual industrial landscapes is revealing of French attitudes, as the balance that observers perceive between industry and "culture", success and suffering, varies according to the traveller's agenda. Where Martin and Erny find harmony, Esquiros and Simonin present "a dystopian vision" and a "warning for France in its ongoing modernization and industrialization" (Singer 2019, 143).

In defence of the biased Celtophiles, it should be pointed out that people were slow to realize that smoke and pollution were a problem. In the French context, such dangers were downplayed, and a belief in workers being unaffected by these is evident in a Traité de la salubrité as late as 1846 (Corbin [1982] 1986, 132). However, a "new form of anxiety" evolves slowly in French thought around mid-century—and by 1866, a "growing attention to noise, dust, and especially smoke" is noted in French writing (134), as seen in an essay of that date by anarchist geographer Élisée Reclus (1830-1905) 'Du sentiment de la nature dans les 


\section{Williams, 15/21}

sociétés modernes' (Reclus 1866, 378). The four Welsh texts discussed in the present article were all written in the early 1860 s, and so the differences of opinion that they display cannot be accounted for by date. It seems unlikely that changes in attitude, and changes in French law on unhealthy habitations and the ventilation of dwellings (160) should have filtered through to the likes of Esquiros and Simonin, but not to Erny and Martin who visited at the same time. On the other hand, French environmentalism has its own particularities; France was later to confront the devastation of nature because the country industrialized later, and Ford suggests this as a reason for France's environmentalism being more aesthetic or cultural $(2016,9)$. Indeed, she suggests that aesthetic and nationalist concerns pollute environmentalism in the French case (15). There is clearly a need to be aware of such differences when ecocritiquing between cultures.

\section{Conclusion}

Cambry and those who followed in his footsteps—-be it in travelogues, fiction or paintingsare responsible for a "place myth" of Brittany that prevented the region from participating in modern history and having industry. The problem with representations of Brittany in the nineteenth century is that they only show the past, or the primitive, as in the case of the enclos-parish enclosures—of Finistère, which are seen as "vestiges of an isolated medieval past, instead of [...] more recent, competitive displays of early industrial wealth" (71 [emphasis added]). Of course, such a view served nineteenth-century tourism very well, as it continues to do today. Far from erasing regional differences, the nineteenth-century French state encouraged and exploited local particularities and sentiments by making provinces "privileged incubators of patriotic sentiments" (Hazareesingh 2015, 188). As I have shown, there were limiting conditions imposed on what the "petite patrie" was allowed to be, as the extractivist state took what it required. In the case of Brittany this was not mineral but rather cultural or aesthetic capital, to support national unity as well as tourism. 


\section{Williams, 16/21}

It has rightly been argued that the growth of the cult of local memories in France relates to France's need to reinvent its past in the wake of the Revolution of 1789 (Dietler 1994). However, the interest in local pasts, which valorized local people-peasants—as repositories of those pasts, was a pan-European movement, with roots stretching beyond the Revolution to Rousseau, beyond the Rhine to Johann Gottfried Herder, and beyond the Alps to Giambattista Vico. Perhaps, then, it had more to do with industrialization and modernization generally; that is to say, with changes to physical environments, rather than with the need for a new nation to forge its myth of origin. This article advocates for a move away from the argument that Celtomania in France is caused by the French Revolution and a need to revisit roots and re-imagine the past; comparison of descriptions of Brittany with texts about Wales suggests that French Celtomania has just as much to do with the Industrial Revolution. On their own, textual depictions of the landscape of Brittany tell us a lot about the changing nature of France during the Industrial Revolution, but we gain a fuller understanding of French regions by viewing Brittany in comparison with another "Celtic" region: south Wales. Caroline Ford has rightly argued that we must look at texts on French colonies in order to understand the development of the discourse on environmentalism in France $(2016,7)$. I argue that we also need to look at travel texts about perceived world leaders in industrialization, particularly Great Britain in its role as France's greatest rival. As has recently been suggested in the case of literature (Roudeau 2018), ${ }^{3}$ regions need to be viewed from a global or transregional (Gosetti and Viselli 2018,61) perspective, rather than being confined to the binary of a relationship with the capital of their nation-state.

\section{Works Cited}

Balzac, Honoré de. (1829) 1972. Les Chouans. Edited by Pierre Gascar. Paris: Gallimard.

Belhoste, Jean-François, and Denis Woronoff. 2005. "The French Iron and Steel Industry during the Industrial Revolution.” Translated by Paul Smith. In The Industrial 


\section{Williams, 17/21}

Revolution in Iron: The Impact of British Coal Technology in Nineteenth-Century Europe, edited by Chris Evans and Göran Rydén, 75-94. Aldershot: Ashgate.

Benoiston de Châteauneuf, Louis-François, and Louis-René Villermé. 1844. "Rapport d'un voyage fait dans les cinq départements de la Bretagne, pendant les années 1840 et 1841." Mémoires de l'Académie des sciences morales et politiques 4: 635-794.

Cambry, Jacques. (1798) 2011. Voyage dans le Finistère. Edited by Dany Guillou-Beuzit. Rennes: Presses universitaires de Rennes.

Coquebert de Montbret, Charles-Étienne. 1995. Voyage de Paris à Dublin à travers la Normandie et l'Angleterre en 1789. Edited by Isabelle Laboulais-Lesage. SaintÉtienne: Publications de l’Université de Saint-Étienne.

Corbin, Alain. (1982) 1986. The Foul and the Fragrant: Odor and the French Social Imagination. Translated by Miriam L. Kochan, Roy Porter and Christopher Prendergast. Cambridge, MA: Harvard University Press. (Originally published as Le miasme et la jonquille: L'odorat et l'imaginaire social, XVIII $-X I X^{e}$ siècles. Paris: Aubier-Montaigne.)

Corbin, Alain. 1988. Le territoire du vide: L'Occident et le désir du rivage, 1750-1840. Paris: Aubier.

Coughlin, Maura. 2013. "Place Myths of the Breton Landscape." In Impressionist France: Visions of Nation from Le Gray to Monet, edited by Simon Kelly and April M. Watson, 67-79. New Haven, CT: Yale University Press.

Coughlin, Maura. 2016. "Biotopes and Ecotones: Slippery Images on the Edge of the French Atlantic." Landscapes 7: 23 pages.

Davies, Sioned. 2004. “A Charming Guest: Translating the Mabinogion.” Studia Celtica 38: $157-78$. 


\section{Williams, 18/21}

Dietler, Michael. 1994. “'Our Ancestors the Gauls:' Archaeology, Ethnic Nationalism, and the Manipulation of Celtic Identity in Modern Europe." American Anthropologist 96 (3): 584-605.

Erny, Alfred. 1867. "Voyage dans le pays de Galles.” Le Tour de Monde 15 (1): 257-88.

Esquiros, Alphonse. 1865a. Itinéraire descriptif et historique de la Grande-Bretagne et de l'Irlande. Paris: Hachette.

Esquiros, Alphonse. 1865b. "Le sud du pays de Galles et l'industrie du fer: Carmarthen, les eisteddfodau et les iron-works de Merthyr Tydfil." Revue des Deux Mondes 55: 80143.

Ford, Caroline. 2016. Natural Interests: The Contest over Environment in Modern France. Cambridge, MA: Harvard University Press.

Glencross, Michael. 1995. Reconstructing Camelot: French Romantic Medievalism and the Arthurian Tradition. Cambridge: D. S. Brewer.

Gosetti, Valentina and Antonio Viselli. 2018. "L' "auoexotisme” des poètes provinciaux: une ruse dix-neuviémiste? Le cas des Amours jaunes de Tristan Corbière.” Romantismes 181: 47-61.

Guest, Revel Guest and Angela V. John. 2007. Lady Charlotte Guest: An Extraordinary Life. Stroud: Tempus.

Harris, John R. 1992. Essays in Industry and Technology in the Eighteenth Century: England and France. Aldershot: Variorum.

Harris, John R. 1998. Industrial Espionage and Technology Transfer: Britain and France in the Eighteenth Century. Aldershot: Ashgate. 


\section{Williams, 19/21}

Hazareesingh, Sudhir. 2015. How the French Think: An Affectionate Portrait of an Intellectual People. London: Penguin.

Hopkin, David M. 2012. Voices of the People in Nineteenth-Century France. Cambridge: Cambridge University Press,

Jones, Peter M. 2016. Agricultural Enlightenment: Knowledge, Technology, and Nature, 1750-1840. Oxford: Oxford University Press.

Landes, David S. (1969) 2003. The Unbound Prometheus: Technological Change and Industrial Development in Western Europe from 1750 to the Present. Cambridge: Cambridge University Press.

Lübbren, Nina. 2001. Rural Artists' Colonies in Europe, 1870-1910. Manchester: Manchester University Press.

Martin, Henri. 1872. Études d'archéologie celtique: Notes de voyages dans les pays celtiques et scandinaves. Paris: Didier.

Orton, Fred, and Griselda Pollock. 1980. "Les données bretonnantes: La prairie de répresentation.” Art History 3 (3): 314-44.

Rearick, Charles. 1974. Beyond the Enlightenment: Historians and Folklore in NineteenthCentury France. Bloomington: Indiana University Press.

Reclus, Elisée. 1866. "Du sentiment de la nature dans les sociétés modernes." Revue des Deux Mondes 63 (mai-juin): 352-81.

Romieu, Auguste. 1829. "La Basse-Bretagne, ses mœurs, son langage et ses monumens." Revue de Paris 2: 155-67.

Roudeau, Cécile. 2018. “Écritures régionalistes (1800-1914): nouvelles échelles, nouveaux enjeux critiques." Romantisme 18 (3): 5-15. 


\section{Williams, 20/21}

Simonin, M. L. 1865. "Une visite aux grandes usines du pays de Galles.” Le Tour du Monde 11 (2): $321-52$.

Singer, Rita. 2019. “Through Wales in the Footsteps of William Gilpin: Illustrated Travel Accounts by Early French Tourists, 1768-1810.” European Romantic Review 30 (2): $127-47$.

Smyers Jr, L. 1858. Essai sur l'état actuel de l'industrie ardoisière en France et en Angleterre. Paris: Poulet-Malassis \& De Broise.

Thuillier, Guy. 1959. Georges Dufaud et les débuts du grand capitalisme dans la métallurgie, en Nivernais, au XIX siècle. Paris: SEVPEN.

Utz, Richard. 2016. “Academic Medievalism and Nationalism.” In The Cambridge Companion to Medievalism, edited by Louise D’Arcens, 119-34. Cambridge: Cambridge University Press.

Vidal-Lablache, Paul. 1889. États et nations de l'Europe: Autour de la France. Paris: Charles Delagrave.

Williams, Heather. 2012. “Celtomania.” In Celtic Culture: A Historical Encyclopedia, 2 vols edited by John T. Koch and Antone Minard, vol. 1, 174-75. Santa Barbara, CA: ABCCLIO.

Williams, Heather. 2019. “La construction du Moyen Âge dans les récits de voyage français portant sur le pays de Galles, ou: Alfred Erny, celtomane en Galles en 1862." In Actes du colloque de Brest, ed. Hélène Bouget and Magali Coumert (Brest: CRBC, forthcoming)

\footnotetext{
${ }^{1}$ Shipbuilding is arguably an exception in this respect.

${ }^{2}$ Hersart de la Villemarqué was the author of the collection and translation into French of Breton ballads Barzaz Breiz (1839) that was famously condemned as a fake. On the strained relationship between Guest and La Villemarqué, and the race to publish a translation of the middle Welsh text 'Peredur' in 1839, which she won,
} 
Williams, 21/21

see Revel Guest and Angela V. John, Lady Charlotte Guest: An Extraordinary Life (Stroud: Tempus, 2007), first published 1989, pp. 109-10.

${ }^{3}$ She argues that local or regional literature is no longer to be understood solely in relation to the nation state (the one to which it belongs), but to be read on a global scale $(2018,8)$. 